\title{
El fascismo se sienta a la mesa
}

Jesús Sepúlveda

Padre sorbe su sopa

y espía el mundo que alrededor se desploma

Madre mira por la ventana

la danza de la muerte que por sus ojos cabalga

El fascismo ha embaucado a la hermana

La niña llora con ojos claros

que botan lágrimas de porcelana

El fascismo se sienta a la mesa

provoca discordia

echa risotadas

El hermano estalla 
La niña se sienta a la mesa

y el fascismo la embaraza

Pare una criatura pelirroja que siente la mano dura en su espalda

Cruje la guerra

El trasero quemado que moja la cama

El castigo

Los correazos

La hermana calla

El fascismo se ha sentado a la mesa

Padre remoja el pan y pierde los dientes

La criatura llora

chilla

y a veces también se queda quieta

Corazón de madre agitado

que palpita

y ora

El fascismo se apropia de la casa

Hace exhibiciones de hombría

grita cuando habla 
El fascismo

piensa en dios

y llora

Sabe humillar

y denosta

Buitres -dice

Comunistas

y se llena la boca con la comida que madre e hija preparan

Es vulgar

y no le importa

Se alegra cuando muestran por la tele

la sombra de los fusilados

Habla de patria y familia

Trizadura en el pasillo

que corre como columna de enfermo

Padre se va curvando en su silla de ruedas

Madre suspira ante el recuerdo de una foto en blanco y negro

Se abre el hueco de la sepultura

Nieta oculta las marcas del horror 
Hasta que un día cumple quince

y su pelo ya no es pelirrojo

sino rubio

y triste como un cuadro de Van Gogh

Entonces el fascismo la embaraza

aborta

la trauma

Y así vive hasta que se casa

Ella misma ya es madre

Luego se separa

y enviuda

Marido muerto en sala de hospital

Esposa en cama por derrame cerebral

El fascismo se hace la víctima

Se queja

Proclama

Pero un día la niña se levanta

y habla

Se recupera

Vomita esa cosa oscura que tenía atragantada 


\section{Fascism Sits at the Table}

Jesús Sepúlveda

Translation by Elmira Louie

Father slurps his soup

and spies on the world that collapses around him

Mother looks out the window

the dance of death riding through her eyes

Sister has been fooled by fascism

The girl cries with crystal eyes

porcelain tears

Fascism sits at the table

causes discord

casts laugher

Brother bursts 
The girl sits at the table

and fascism impregnates her

Gives birth to a redheaded creature who feels a hard hand on her back

War groans

A burned bottom wets the bed

Punishment

She gets hit with a strap

Sister is silenced

Fascism has sat at the table

Father soaks the bread and loses his teeth

The creature cries

screams

and sometimes also stays still

The heart of a disturbed mother

throbs

and prays

Fascism seizes the house

Makes exhibitions of manhood

shouts when it speaks 
Fascism

thinks about god

and cries

Knows how to humiliate

and insult

"Vultures"-it says

"Communists"

and fills its mouth with the food mother and daughter prepare

It's vulgar

and doesn't care

It rejoices when they show on TV

the shadow of the executed

It speaks of homeland and family

Crack in the corridor

runs like a patient's spine

Father sags in his wheelchair

Mother sighs at the memory of a black and white photo

The burial hole opens

Granddaughter hides the marks of horror 
Until one day she turns fifteen

and her hair is no longer red

but blonde

and sad like a painting by Van Gogh

Then fascism impregnates her

she aborts

is traumatized

And so she stays until she gets married

She is herself a mother now

Later she separates

and is widowed

Husband died in hospital room

Wife in bed after a stroke

Fascism plays the victim

Complains

Proclaims

But one day the girl gets up

and speaks

She recovers

Vomits the dark thing that had choked her 